\title{
Amyotrophic lateral sclerosis: Ethical challenges
}

Claudio Crisci, MD, Private Hospital for Rehabilitation, Naples, Italy: In the February 2011 issue of Neurology: Clinical Practice, Johnston et al. ${ }^{1}$ address the ethical issues amyotrophic lateral sclerosis (ALS) raises in a professional and compassionate manner. Nevertheless, some "unethical" thoughts come to mind. Doctors should not behave with an impersonal attitude, should be compassionate, and should not abandon patients even if faced with unacceptable requests. Is assisted suicide an unacceptable request? All of us have experienced assisting a dying patient with ALS and such a request should be addressed in a very thoughtful way. To withdraw a patient from a ventilator under a palliative sedation is more scientific and probably considered more ethical, while assisted suicide is seen as more sudden and dramatic but perhaps less devastating and less financially burdensome to the family. The economic issue sounds outrageous but insurance companies or private health care facilities are greedy. The patient had a previous tragic experience and instinctively asked for a rapid death to avoid a long-lasting agony. He knew that if he had deferred the issue to a surrogate decision-maker, it would have been impossible to respect his wish to die rapidly. The patient identified the right shortcut for him and his family from the economic and emotional point of view.

Disclosures: The author reports no disclosures.

Correspondence to: claudiocrisci@live.it

Charles K. Jablecki, MD, University of California San Diego: In the February 2011 issue of Neurology: Clinical Practice, the article by Johnston et al. ${ }^{1}$ covered many ethical issues that have arisen in my practice in the evaluation and management of several hundred patients with ALS over the past $30+$ years. I suggest you consider an alternative phrase to "Physicians cannot abandon patients, even if faced with unacceptable behavior or requests." I recommend replacing it with "Physicians should try to continue to work with their patients, even in the face of behavior or requests that seem unreasonable. The request or behavior should prompt an inquiry with the hope of identifying the basis of the request or behavior with the hope of providing alternative approaches to address the patient needs that underlie the request or behavior." There are situations where a physician should transfer care of a patient with ALS to another physician for further care. In my own practice, if a patient elects to have a tracheostomy and use continuous mechanical ventilation, I have the pulmonologist assume primary care as I do not have the experience to manage the patient's daily needs. I have not "abandoned" the patient. Finally, there are instruments to help estimate the time from the onset of weakness to the development of respiratory insufficiency leading to death. ${ }^{2}$

Disclosures: The author reports no disclosures.

Correspondence to: jableckimd@gmail.com

Authors Respond: Wendy S. Johnston, $\operatorname{MD}, \operatorname{FRCP}(C)$, University of Alberta, Canada; Katelin Hoskins, MSN, MBE, Leo McCluskey, MD, MBE, University of Pennsylvania: We thank Dr. Crisci for his comments.

Any practitioner may be faced with a request that he or she deems unacceptable; the general principle is to look beyond the request to the impetus and to respond with empathy to the underlying motivation. To respond with compassion does not obligate a physician to comply with the request. 
Most ethicists distinguish forgoing or withdrawing life-sustaining therapies from physicians hastening death (assisted suicide or euthanasia). It is debatable whether a family would regard suicide (whether physician-assisted or not) as less devastating than a planned withdrawal from a ventilator.

Initially addressing the patient's perceptions that ALS could only be a "long-lasting agony," presenting the current interventions and strategies that improve quality of life as well as potentially extend meaningful life, may have prevented the chaos and distress that ensued. Fear of future suffering as well as concerns about burdening family are the most prominent reasons for interest in hastening death. The desire to remain autonomous and in control is also a major motivation. Physician-assisted death is legal in only a few jurisdictions; concerns that it might be viewed as "convenient" may be a motivating factor to those who oppose it.

Dr. Jablecki's thoughts and suggestions are appreciated. The positive reframing of the statement about physicians remaining available to their patients with ALS is welcome. In no way do we feel that appropriate transfer of care, in situations as you describe, represents abandonment. In fact, standard of care would suggest that all patients with ALS be offered care at a specialty multidisciplinary clinic; referral to an ALS clinic does not represent abandonment, but the original physician should not assume the other physician or clinic has taken over until the patient is actually seen or enrolled.

Thank you for drawing our attention to your article about predicting survival. Patients and families often wish to have discussions about prognosis and expectations of timing of interventions. We feel that these are appropriate when tailored to the individual and should occur only after enough information has been gathered over several clinical assessments so as to be meaningful. What we decry is the all-too-familiar statement (or variation thereof) given to patients and families at the time of diagnosis that "average survival is 2 years (or 18 months or 3 years)." In what other neurologic condition is the information so baldly conveyed? The progression of disability and timing of decisions about respiratory and nutritional interventions is highly variable. At the time of diagnosis we honestly do not know what the course will be, so we feel that it is inappropriate to convey these population-based statistics as part of breaking the news.

Disclosures: See original article for full disclosure list.

Correspondence to: wendy.johnston@ualberta.ca

1. Johnston WS, Hoskins K, McCluskey L. Amyotrophic lateral sclerosis: ethical challenges. Neurology 2011;76:S1-S5.

2. Jablecki CK, Berry C, Leach J. Survival prediction in ALS. Muscle Nerve 1989;12:833-841.

\section{The evaluation of polyneuropathies}

Jaume Revuelto-Rey, MD, Juan J. Egea-Guerrero, MD, Francisco Murillo-Cabezas, Virgen del Rocio University Hospital, Seville, Spain: We enjoyed reading the Burns et al. ${ }^{1}$ article about the evaluation of polyneuropathies but missed the discussion of critical illness polyneuropathy.

It is the primary axonal degeneration of motor and sensory fibers that can lead to degeneration of muscle fibers. This occurs in critically ill patients, including those with systemic inflammatory response syndrome, sepsis with multiple organ dysfunction syndrome, hyperglycemia, or in those requiring muscle relaxants, corticosteroids, or parenteral nutrition. This may occur in up to $80 \%$ of critically ill patients, usually in the form of quadriplegia or quadriparesis, with abolished tendon reflexes and no pathologic changes in the CSF. ${ }^{2}$

The neurophysiologic study shows primary axonal degeneration of motor and sensory fibers with preservation of conduction velocity, normal distal latency, and potential fall of 


\section{Neurology ${ }^{\circ}$ Clinical Practice}

Amyotrophic lateral sclerosis: Ethical challenges

Claudio Crisci, Charles K. Jablecki, Wendy S. Johnston, et al.

Neurol Clin Pract 2011;1;2-3

DOI 10.1212/CPJ.0b013e31823fdda2

This information is current as of December 1, 2011

$\begin{array}{ll}\begin{array}{l}\text { Updated Information \& } \\ \text { Services }\end{array} & \begin{array}{l}\text { including high resolution figures, can be found at: } \\ \text { http://cp.neurology.org/content/1/1/2.full.html }\end{array} \\ \text { References } & \begin{array}{l}\text { This article cites } 2 \text { articles, } 1 \text { of which you can access for free at: } \\ \text { http://cp.neurology.org/content/1/1/2.full.html\#\#ref-list-1 }\end{array} \\ \text { Permissions \& Licensing } & \begin{array}{l}\text { Information about reproducing this article in parts (figures,tables) or in } \\ \text { its entirety can be found online at: } \\ \text { http://cp.neurology.org/misc/about.xhtml\#permissions }\end{array} \\ \text { Reprints } & \begin{array}{l}\text { Information about ordering reprints can be found online: } \\ \text { http://cp.neurology.org/misc/addir.xhtml\#reprintsus }\end{array}\end{array}$

Neurol Clin Pract is an official journal of the American Academy of Neurology. Published continuously since 2011, it is now a bimonthly with 6 issues per year. Copyright Copyright $₫ 2011$ by AAN Enterprises, Inc.. All rights reserved. Print ISSN: 2163-0402. Online ISSN: 2163-0933.

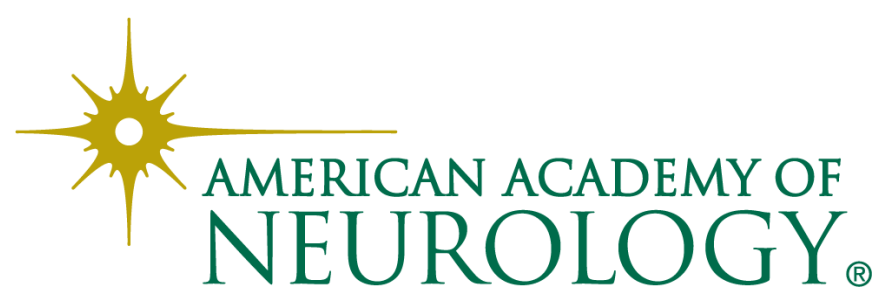

